\title{
Development and Marketing of Solar Innovations: A Case Study
}

\author{
Harald Wirtz', Markus Janssen²
}

\begin{abstract}
This study aims to examine the process of development and marketing of CIS (copper-indium-selenium) technology as a major innovation in solar technology through the case of Würth Solar, which is the first company worldwide to have started mass production of CIS-solar modules. This article reports the development history of the technology and analyzes its innovative content. It also describes cooperation with innovation partners as a key to success. The participating organizations and actors involved are shown and their roles in the innovation process are illustrated. Challenges and oppositions are explained and the way the company managed to overcome these difficulties is presented.
\end{abstract}

Keywords: solar technology; innovation cooperation, dimensions of innovation; promoters; opposition.

\footnotetext{
' Fraunhofer Institute for Technological Trend Analysis, Appelsgarten 2, 53879 Euskirchen, Germany. Tel.: +49 225 I 18237. E-mail: harald.wirtz@int.fraunhofer.de

${ }^{2}$ Accenture GmbH, Kaistr. 20, 4022 I Düsseldorf, Germany. Tel.: +49 21 I 9120 64228. E-mail: markus.janssen@accenture.com
} 


\section{Introduction}

\section{I.I Growth Market Solar Technology}

As an energy source, the sun has a significant advantage compared to conventional energy sources such as oil, natural gas or coal. While these exist only to a limited extent and will be exhausted in the not too distant future, the sun will still shine for millions of years. The solar energy hitting the land surface is a multiple of the annual primary power demand of the world. In addition, solar energy is practically free of emissions.

Many forecasts, such as for example a study of the Scientific Advisory Board of the Federal Government of Germany (WK German Government, 2003), predict a significant increase in the use of solar energy in the coming decades. The production of solar cells has in fact expanded in recent years with considerable growth rates. This represents a huge market. Turnover from the installation of photovoltaic systems in 2008 in Germany alone amounted to 7.9 billion Euros (BMU, 2009). Currently about $85 \%$ of solar panels are made from crystalline silicon (Hirshman et al., 2009). About 15\% are so-called thin-film cells, that allow much thinner semiconductor layers by using other materials and production processes. Particularly relevant in this context are cadmium telluride, amorphous silicon and CIS technology (Wittwer, 2009).

$\mathrm{CIS}$ is the generic term for semiconductors consisting of a combination of copper, indium, optional selenium or sulphur and sometimes further elements (e.g. gallium). The special qualities of the materials allow the production of photovoltaic modules with an active, light-sensitive layer of just a few micrometer thickness, while conventional silicon modules require a layer thickness of 100 - I50 micrometer. Among the thin-film cells, CIS reaches the highest efficiency rates with $20 \%$ in laboratory scale (Papathanasiou, 2008) and about $12 \%$ in industrial quantity production (Fuhs, 2009).

\section{I.2 Investigation Objective and Methodology}

In this case study we want to analyze the development and dissemination of $\mathrm{ClS}$ technology as a major innovation in solar technology. The focus is set on the development history of the technology, its innovative content, the participating organizations and actors involved and their role in the innovation process, as well as cooperation and opposition. Among the leading organizations we concentrate on the cooperation between the Institute of Physical Electronics (IPE) at the University of Stuttgart, the Center for Solar Energy and Hydrogen Research (ZSW) Baden-Württemberg and the Würth Group. This cooperation holds a pioneer role in the development of the technology and was the first to start mass production of CIS panels.

For information retrieval a methodology based on three core elements was chosen:

- As a first step, we collected and evaluated all available open sources such as journals, business reports, websites etc. in order to retrieve information about the history and function of the technology and to find the organizations playing a crucial role in the development and commercialization.

- These findings were extended on the basis of expert interviews in order to allow an assessment of the innovation content of the technology. This way we could also identify the main protagonists of the development and marketing of the technology. All interviewees were longstanding experts for the technology but were not involved in its development or marketing.

- To obtain internal insight into the process of development and the management of the innovation, we interviewed a key person who himself was decisively involved in the innovation process. During his career, the interviewed expert worked in three organizations that had been identified in both preceding analysis steps as key drivers of the development and market introduction of CIS technology, namely IPE, ZSW and the company WürthSolar. Therefore, he was able to provide information about the entire process and different key actors. Currently the expert is working as CEO of Würth Elektronik Research, which pursues the R\&D for Würth Solar.

\section{CIS technology}

\section{I History of Development}

The CIS material was presented for the first time in 1953 by Hahn in Stuttgart, Germany. In 1974, Sigurd Wagner could produce the first solar cells made of CIS 
single crystals at Bell Laboratories. In the following years several laboratories worldwide worked on increasing the efficiency of cells in the laboratory scale. Mickelson and Chen of Boeing Corp managed to create the first thin-film solar cell based on CIS with $10 \%$ efficiency in 1984 (ZSW, 2006). The current world record of $20 \%$ is held by the US National Renewable Energy Laboratory NREL since 2008 (Papathanasiou, 2008). ZSW reached a new European record in 2009 with 19.6\% (ZSW, 2009). All these records relate to laboratory cells with a size of only a few $\mathrm{mm}^{2}$. For larger cells or modules, which are actually used for power generation, efficiencies are lower (Wittwer, 2009).

According to the conducted expert interviews, the leading research institutions in CIS technology in Europe were the Institute of Physical Electronics (IPE) at the University of Stuttgart, the University of Uppsala, Sweden, and the Hahn-Meitner-Institut (HMI) Berlin. The University of Stuttgart achieved cell efficiencies of 15 to $17 \%$ in 1989 (ZSW, 2006). At this stage of development, a cooperation with the Center for Solar Energy and Hydrogen Research (ZSW) was started in order to jointly develop the technology on a pilot scale in preparation for industrialization. Later, the Würth Group became the third partner and founded the company Würth Solar in 1999. Würth produced the first pilot line in 2000 and was the first company worldwide, that started mass production of CIS modules in 2006 (Karg, 2009; Dimmler, 2009). In the next years some followers entered into production, so that today about half a dozen enterprises run mass production of CIS modules in addition to some smaller manufacturers.

\subsection{Structure and Function of CIS Solar Cells}

All types of solar cells follow the same functional principles. The main components of a solar cell are two differently charged semiconductor layers. Semiconductors are materials that have electrical conductivity between conductors and insulators. The conductivity rises with temperature or incidence of light. The sunlit semiconductor layer has a surplus of electrons and is therefore a negative conductive so called n-type semiconductor. Beneath this there is a positive so-called $\mathrm{p}$-type-semiconductor. In conventional silicon cells the different charge is realized by a purposeful contamination of the semiconductor material with other atoms, the so-called doping. Silicon is an element with 4 electrons on the outside shell. It becomes an n-semiconductor when atoms with 5 electrons on the outside shell (e.g. Phosphorus) are inserted and a p-type semiconductor when an element with 3 electrons is inserted (e.g. Boron) (Brand, Hoffknecht, Krauss, 2009).

When sunlight hits the $n$-type semiconductor layer, the energy dissolves the electrons from their places in the atom structure. Although they are attracted immediately by the deserted atoms, they cannot return to the original positions, because at the junction of the $\mathrm{n}$-semiconductor layer to the $\mathrm{p}$-semiconductor layer, there is an inner electric field, which induces a charge separation. The electrons have to follow the outer conductor. When the outer circuit is closed by connecting an electrical load, DC power flows. This can also be converted into AC using an inverter (Wittwer, 2009).

The specific feature of CIS cells is the semiconductor material that is used instead of conventional silicon. Basically there is not a single CIS technology. Nearly every manufacturer uses its own composition of the semiconductor layer and its own production processes. There is even confusion concerning the name of the technology. Some producers call it CIS, others CIGS, CIGSe or CIGSSe. The first two letters stand for the elements copper and indium. The $\mathrm{S}$ may represent either selenium or sulphur. Sometimes also the abbreviation $\mathrm{Se}$ is used for selenium. The $\mathrm{G}$ represents gallium, which is added by some manufacturers. The following figure shows the basic structure of CIS cells and the specific configurations of the leading manufacturers. 


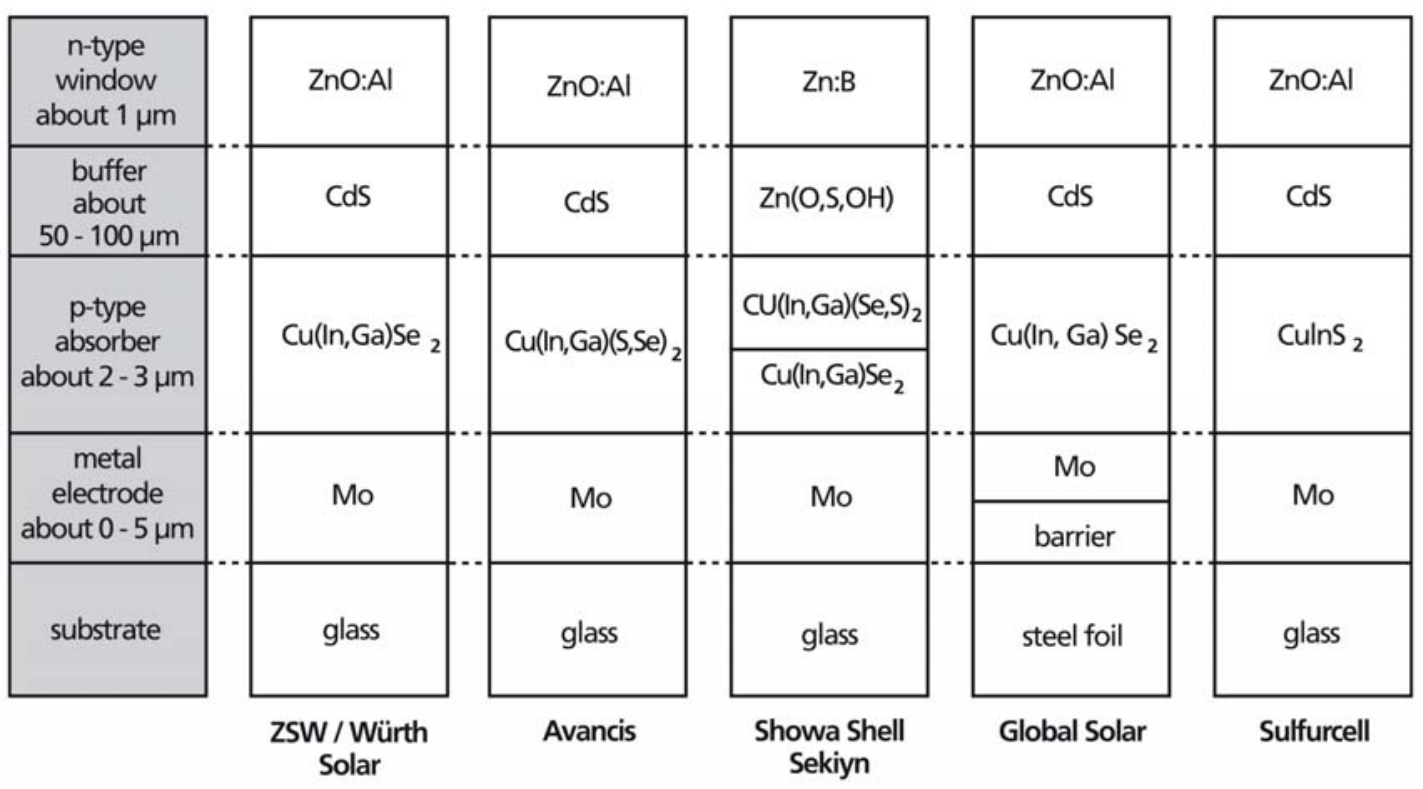

Figure I. Structure of CIS Cells by leading manufacturers, Source: Fuhs (2009), p. 5 I

The basic structure is the same in all CIS cells. Below is a substrate on which the other layers are applied, usually glass. In part also stainless steel foil is used as a substrate. On the substrate there is a thin contact layer, usually made of molybdenum. Depending on the substrate and manufacturing method, the molybdenum is also a barrier to the diffusion of interfering substances into the semiconductor, e.g. sodium ions from the glass substrate. The CIS material is laid on the molybdenum as a p-type semiconductor. While in conventional silicon cells, the different charge of the semiconductor layers is achieved by a different doping with other elements, CIS cells use a completely different material as n-type semiconductor such as a thin cadmium sulphide layer in conjunction with a thicker zinc oxide layer, partially doped with aluminium. The zinc oxide fulfils the functions of the transparent window and the negative pole (ZSW, 2006; Fuhs, 2009)

CIS material permits substantially lower layer thickness than customary silicon due to its higher light absorption. In addition, it allows influencing of the so-called band gap by varying the mixing ratio of the individual components of $\mathrm{CIS}$. The band gap means, in simple terms, the energetic distance between the bound and the moving electron. It represents the minimum energy that a light photon has to give to the electron to eject it from the atom. In silicon the band gap is approximately $\mathrm{I} . \mathrm{I}$ electron volts. This is so little that even the relatively low-energy infrared photons excite the electrons over the band gap. But also the much more energetic blue light particles can move only one electron. The energy difference is lost as heat. Therefore the optimum is a band gap, which brings out as much energy as possible from the sunlight, which is a specific mixture of infrared to ultraviolet light. This optimum is after knowledge of theoretical physics at I.4 electron volts (Fuhs, 2009). By varying the mixing ratio of the elements the band gap in CIS cells can be varied from 1.04 to 2.7 electron volts. Thus the optimal value is attainable. It is also possible to design the semiconductor material in a way, that the band gap is not uniform everywhere, but can increase or decrease over the depth of material (Fuhs, 2009). Therefore an infinite number of variations is possible to optimize the efficiency. This quality represents a big potential on the one hand and, on the other hand, can be respected as a reason for the fact that up to now no standardized procedure has evolved.

\subsection{Evaluation of the Technology}

The manufacturers of CIS modules claim a number of advantages for the technology (Würth Solar, 2010, Sulfurcell, 2009).

- Saving material: CIS technology saves $95 \%$ of semiconductor material compared to common silicon wafers. 
- Production costs: Because of the small quantities of materials and the different manufacturing process, the production costs per watt are relatively low.

- Energy payback time: CIS modules need a relatively short time to generate more energy than the amount that was used for their own production.

- Aesthetics: CIS modules have a homogenous black to anthracite look with fine pinstripes similar to dark colored glass. Therefore the modules can be used as attractive architectural elements in buildings.

- Adaptability: The modules have a high flexibility concerning measures and geometry, making them even more attractive for integration in buildings.

- Shadow tolerance: CIS modules have a relatively high tolerance against shadow, e.g. by trees, buildings etc.

- Potential: The potential for further development of CIS technology is far from being exhausted. On the one hand, the efficiency can still be raised by modification of the mixture of semiconductor materials. On the other hand, totally new applications can be developed by using flexible carrier materials, e.g. integration to tent roofs, sails or clothing. Yet, for this purpose some technical problems have to be solved first.

But all these arguments should be handled with care. Although the technology has made progress, CIS modules are still behind with efficiency compared to silicon modules. While industrial made $\mathrm{CIS}$ modules have efficiency rates of $12 \%$, multicrystalline silicon modules have $18.5 \%$ and monocrystalline ones even up to $20 \%$ (Dimmler, 2009, Fuhs, 2009). Up to now, this disadvantage in efficiency cannot be compensated by lower production costs. At the moment, costs are at the same level as silicon modules at about 2.6 \$ per watt (Rentzing, 2009). Currently the lowest production costs can be realized by the company First Solar with, according to their own information, under I \$ per watt on a basis of cadmium telluride (First Solar, 2009). But a disadvantage of this technology is the higher demand for surface due to its lower efficiency. In addition, the heavy metal cadmium is toxic and makes the production and disposal more complicated. With all solar technologies further cost reductions seem probable in the near future. CIS manufacturers will be able to realize this already by the advantages of the only beginning mass production. Yet, it has to be noted, that in fact CIS needs considerably less semiconductor material than silicon cells, but the chemical elements in use are comparably rare and are used for other mass products, too. Indium for example is also used for LCD screens of notebooks, televisions and cell phones (Hannen, 2009). A rising demand could very quickly lead to an increase in raw material prices. This also is a disadvantage in the sense of a sustainable use of natural resources compared to silicon, which is available on large scale.

In this context the energy payback time is an important criterion. In fact thin-film technologies reach significantly shorter energy payback times compared to conventional silicon technology (NREL, 2004). With an expected lifespan of 20 years, a CIS module produces as much energy in the first two years as was needed for its own manufacturing, while silicon modules have an energy payback time of 5 to 7 years. But even in that criterion the cadmium telluride technology reaches the best value with I.5 years (Helmholtz, 2009).

At the moment there seems to be differentiated use of the technologies according to conditions and purposes. For classic roof systems mostly traditional silicon modules are used, because they can better exploit the limited available surface due to their higher efficiency. For ground-mounted systems, both crystalline silicon cells and thin-film cells are used. For example the world's largest open space solar power plant in Albacete, Spain, with 41,600 solar panels and a total of 3.26 megawatts, uses CIS solar cells (solarserver, 2008). Thin-film cells and especially CIS cells are preferably chosen where they can be used as a combination of architectural design elements and energy generator, for example in form of semi-transparent glass panels that provide sun protection on the one hand and harvest the solar energy on the other. An example of such an application is the Beijing South Railway Station, which is currently still under construction. It will be equipped with CIS solar modules of Würth Solar in the described manner.

\section{Dimensions of Innovation}

In this section we will examine the innovation quality of $\mathrm{CIS}$ technology. According to the definition of Fichter, 
innovation is the development and enforcement of a technical, organizational, business-related, institutional or social problem solution, which is perceived as fundamentally new, accepted by relevant users and run by innovators in the expectation of success (Fichter, 2009). This definition can be specified more precisely by the concept of five key dimensions developed by Hauschildt (Hauschildt/ Salomo, 2007).

- Content dimension: What is new?

- Intensity dimension: New to what extent?

- Subjective dimension: New and acceptable to whom?

- Normative dimension: New equals successful? Successful in what way?

- Procedural dimension: Where does the innovation begin, where does it end?

The content dimension can be differentiated into technical (new products, procedures), organizational (new forms of work, structure, process organization), business-field-related (new service concepts, procurement and sales markets etc.), institutional (new mechanisms or systems) and social innovations (new social life forms). CIS technology is a technological innovation. It is primarily a process innovation, because it uses a new factor combination to produce a cheaper and better quality good. The technology also enables product innovation, because a benefit is offered, which allows the user to meet new purposes or to achieve existing purposes in new ways.

Crucial for determining whether a project represents an innovation in the intensity dimension is the level of innovation. Important to the assessment is the question of whether there is a discontinuity in the sense of Schumpeter (Schumpeter, 1931). At the time of its development, new for CIS technology was the replacement of silicon by the CIS semiconductor material. Since other raw materials are used, there are also other procurement channels. Also completely new production methods are needed. Because the active lightsensitive layer is only a few micrometers thick, there are new fields of application too. Regarding this, CIS technology meets all requirements for an innovation in the intensity dimension.
Within the subjective dimension there are four levels: world novelty, national novelty, industry or market novelty and company novelty. As stated above, the development was carried out in parallel at many laboratories worldwide. Therefore no single institution can claim world or industry novelty in development. In Europe IPE and ZSW were the leading pioneers. Based on this scientific knowledge, Würth Solar was the world's first company that built mass production of CIS solar modules.

In the normative dimension, the question is whether new means successful. Success may be understood in several ways. From the perspective of the innovating company, the criterion is especially the distribution in the market. So ultimately the question is whether the innovation is a business success. Meanwhile CIS modules are manufactured in high volume and successfully marketed, so from an entrepreneurial point of view the technology can be seen as successful. From the perspective of customers and users there is a success, because it adds a recognizable value over previous products or alternative offers. From the perspective of politics and society, the technology can be regarded as successful, due to the fact that it created jobs at the producer, supplier and distributor companies and its dissemination contributes to climate protection. Overall, CIS technology can be described as a success in any of these views.

In the procedural dimension it has to be decided where the innovation starts and where it ends. The beginning of an innovation project is typically marked by the idea (Hauschildt/ Salomo, 2007). After the development of the CIS material at the University of Stuttgart in the 50's, the idea to use the semiconductor for solar cells was pursued in several laboratories worldwide. This can be seen as the beginning of the innovation process. The end of the innovation process is marked by the introduction of the new product in the market. This point was reached at the latest with the transition from pilot production to volume production, which occurred around 2006 through various producers. In this view, the innovation process can be regarded as completed. Despite this, work is continuing in the research departments of the producers as well as at universities and other research institutions. As far as this leads to more than incremental improvements, e.g. new applications with flexible substrates, these may become new innovations. 
Overall, according to a synopsis of the discussed dimensions, CIS technology is considered a very significant innovation in the production and use of solar cells.

\section{Innovation Process by the Cooperation Partners Würth, ZSW and IPE}

The following section focuses on the innovation process between Würth, ZSW and IPE. As a first step, the development process of CIS technology will be described. The next step is the presentation of the cooperation and development partners and the analysis of their different motivation and roles in the innovation process. Following, the resistance within the innovation process will be analyzed and a description is given of how the resistance could be overcome. With regard to this resistance the next section will focus on the promoters and their role during the innovation process. Furthermore, how they pushed the innovation process of CIS technology will be evaluated. In the last section, attention will be given to the experiences of the innovation process through Würth Solar.

\section{I The Way from Laboratory to Volume Production}

The innovation process of $\mathrm{CIS}$ took 30 years from the fundamental research to large-volume production.

Based on the American fundamental research results, at the beginning of the 70s, the innovation process of CIS thin-film technology was launched in Germany by the IPE under the leadership of Prof. Dr. W. Bloss in 1975. The IPE was significantly involved in the fundamental research of thin-film solar cells. On the basis of their research, they succeeded in producing a CIS cell of $\mathrm{Icm}^{2}$ with an efficiency of $17 \%$ (ZSW, 2006). Due to that result, CIS technology became more and more attractive, resulting in the IPE agreeing on a cooperation with the ZSW. The purpose of this cooperation was to develop CIS technology to a pilot plant scale $(30 \mathrm{~cm} \times 30 \mathrm{~cm})$ with the midterm goal of developing mass production technology, enabling the production of $120 \times 60 \mathrm{~cm}^{2}$ modules. Within the scope of the EuroCIS project in 1995, a small module with a size of $100 \mathrm{~cm}^{2}$ and an efficiency of more than $10 \%$ was successfully developed. With these results the ZSW and IPE proved that large-volume production possesses high economic potential. For further development to a pilot plant scale the IPE and ZSW found an industrial partner named Phototronics Solartechnik (PST). In 1997, the cooperation succeeded with pilot plant scale development of a CIS module. Due to their new strategy, PST left the cooperation after this success (University of Stuttgart, 2006).

Since the exit of PST, the ZSW and IPE sought a new industrial partner. In 1999 the Würth Group joined the cooperation as a partner for the industrial manufacturing of CIS modules. Based on that cooperation and with financial support from EnBW, Würth Solar GmbH \& Co. $K G$ was established in 1999. The pilot production line with a capacity of 1.2 MWP was built in Marbach near Stuttgart. In 2003, after EnBW left the cooperation, Adolf Würth $\mathrm{GmbH}$ took over the shares from EnBW with the aim of developing a large-volume production. After around six years of development and investments of 40 million euro, Würth succeeded in reaching the stage of large-volume production for CIS modules in 2006. Based on these results Würth invested further 55 million euro in a new CISfab plant with a capacity of 14,8 MWP in 2007. A further expansion stage was reached one year later enabling Würth to produce $30 \mathrm{MWp}$ with an annual outcome of 350,000 GeneCIS photovoltaic modules. Würth was the first company worldwide with a largevolume production for CIS modules. (ZSW, 2006)

\subsection{Cooperation Partners and their Motivations}

Within the innovation process it was possible to identify three main cooperation partners who were significantly responsible for the success of the innovation. In the following section the cooperation partners will be introduced and the degree of cooperation described in order to reveal their motivations for the cooperation.

\section{IPE}

The IPE is an institute of the University of Stuttgart which employed 32 employees in 2009. From 1975 - 2005 the IPE focused on the fundamental research within the material and process development of CIS technology. Since 2006, the IPE left the fundamental research for CIS technology and started research activities around the silicon material. The gained "Know-how" was transferred to the ZSW. (IPE, 20I0) 


\section{ZSW}

The ZSW was established as a public trust in 1988 with the purpose of conducting and promoting research and development in the field of solar energy and hydrogen technology in co-operation with university and nonuniversity research and of transferring the results into industrial application. Founders of the ZSW were BadenWürttemberg, a federal state of Germany, the University of Stuttgart, the German Aerospace Center and, amongst 12 other companies, the Adolf Würth GmbH \& Co. KG. (ZSW , 20I0b)

With 150 employees, the ZSW is located in Stuttgart, Ulm and Widderstall and is mainly financed through third-party funds. In 2008, the proportion of third-party funds was around 15.5 million euro of a total 19 million euro turnover. (ZSW, 20I0a)

\section{Würth Group}

The Würth Group was established in 1945 by Adolf
Würth. Following his death in 1954, his son Reinhold Würth led the company. Under his leadership the company grew to become an international player with a 9 billion Euro turnover and 63,000 employees. In 2008 Würth generated a profit of 367 million Euros with 416 companies in 86 countries. The success of the Würth Group depends largely on its sales force which encompasses 28,000 employees. The main business is worldwide trade in connecting and assembly technology. With the investment in so-called allied companies, Würth Group operates in markets and business segments close to their core business. The Würth Solar $\mathrm{GmbH} \&$ Co. KG is therefore exemplary (Würth, 20I0)

\section{Würth Solar GmbH \& Co. KG}

The Würth Solar GmbH \& Co. KG was established in 1999 as a cooperation between the Würth Group, ZSW and EnBW. With a holding of $20 \%$ of shares, the EnBW provided only financial support for the cooperation. In 2003, EnBW left the cooperation and Würth took over their shares.
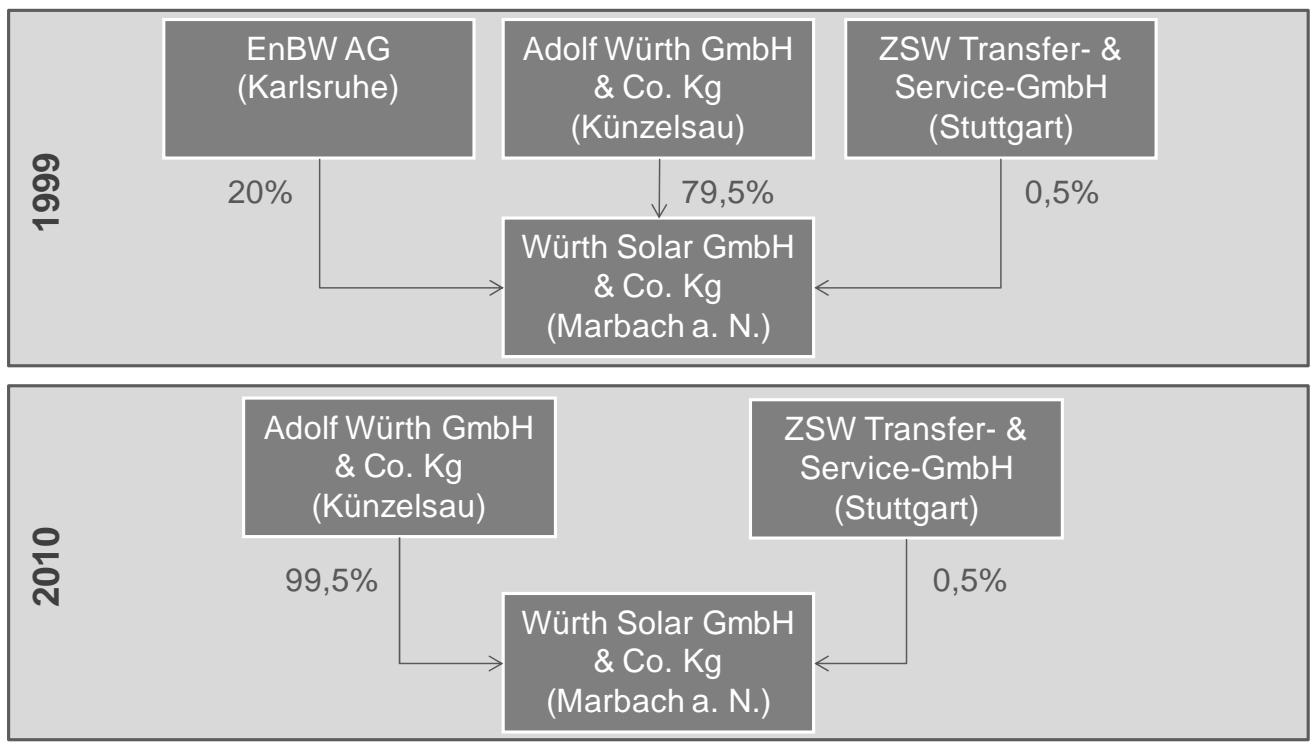

Figure 2: Development of the Würth Solar shareholder structure, Source: Own illustration

Since 1999 Würth Solar continuously grew and generated a turnover of around 63 million Euros in 2007, at that time with around 200 employees. For Würth Solar the key to obtaining a sustainable edge on the competition is to innovate. For that purpose Würth Solar established the Würth Elektronik Research in Stuttgart in 2006. The goal for Würth Elektronik Research is the functional attendance for large-volume production and the increase of efficiency. A further aim is the optimization of the production technology, in order to reduce the production costs and to increase the outcome. (Würth Solar, 2010) 


\section{Cooperation \& Motivation of the Cooperation}

Cooperation can be described as the collaboration between two or more companies with a common goal to do one or more projects together. There is a variety of reasons why companies do cooperate (Fichter, 2009).

- Gain knowledge (know-how)

- Generating synergy effects

- Reduction of development time

- Cost reduction, avoiding double work

- Facilitation of market entry

- Reduction of development risks, distribute the share of risk

- Establishing standards

- Economies of scale

- Enabling projects which are not possible to realize for one company

- Support for the entrance in a new field of technology.

During this innovation process there are two cooperations that played a central role. On the one hand, the cooperation between the IPE and ZSW, which developed the innovation up to a pilot plant production stage, and on the other hand ZSW, Würth Group and EnBW, which founded the Würth Solar and set up the large-volume production. In both cases there is vertical cooperation, since the cooperation partners manage different parts of the value chain.

- IPE - Focuses on fundamental research and development on laboratory scale

- ZSW - Focuses on application oriented research with know-how in production technology; development up to the pilot plant scale stage

- Würth Group - Industrial partner with strong sales force and distribution network and know-how in largevolume production

The first cooperation between IPE and ZSW was characterized by knowledge exchange and led to a knowledge gain on both sides. The main motivation for the cooperation was to reach a pilot plant scale stage in order to show the industry the possible economic success and to raise their interests for CIS technology. This motivation can also be found in the purpose of the ZSW trust.

The second cooperation between ZSW and Würth Group aimed to reach large-volume production. In addition, the ZSW sought a cooperation partner who would take the risk of investing in a pilot production line. The Würth Group took the risk, being aware that Würth Group would not generate any profit for the first couple of years and that competitors could be first to the market. Another reason from the perspective of ZSW was the financial resources and the "know-how" of large-volume productions provided by the Würth Group. Furthermore, Würth offered a strong sales force and distribution network through their subsidiary Solergy.

Würth Group on their side saw a new growing market with a huge potential in CIS technology. Furthermore, Würth could benefit from the earlier research results between ZSW and IPE.

All in all, it was a "Win-Win" situation for both cooperation partners since each core competences complemented other core competences.

\subsection{Resistance and Overcoming}

An innovation process is always accompanied by resistance. For a successful innovation it is essential to identify the location of resistance and to react as soon as possible. In general it is possible to cluster the location of resistance into two parts, internal and external resistance. (Brockhoff, 2007) Following, it is necessary to analyze which arguments the opponents have. These arguments can be clustered into five further sections (Fichter, 2009):

- Technical arguments

- Sales related arguments

- Financial and economic arguments

- Ecological arguments

- Social arguments)

The scepticism and subsequent resistance against $\mathrm{CIS}$ technology came mainly from external sources, such as politics and industry. Both stakeholders brought up financial and economic arguments. The challenge was to 
convince the politicians to provide public funds for the thin-film technology in order to win over an investor from the industry. According to our interview partner a determining factor to overcome the resistance was the persistence of the promoters and several technical developments, which demonstrated the market potential of CIS technology.

\subsection{Promoters}

As shown in the last section, the promoters were the determining factor in overcoming the resistance. Promoters have the task to push the innovation process (Vahs/Burmester, 2002). Therefore, the promoters can be clustered into four different groups:

The "Power Promoter" is presented by a person from the top management or in a similar hierarchy position. Based on his/her authority he/she is able to set priorities and milestones. Furthermore he/she is able to support the innovation process with resources. His/her task encompasses the protection of the "Functional Promoter" and the overcoming of barriers of "Not willing".

The "Functional Promoter" possesses functional knowledge and the methodology competence within the innovation process. His/her focus is to push the functional development. He/she knows critical details, formulates and stimulates visions and supports functional problems. His/her main tasks encompass the development of solutions, the assessment of solutions and the overcoming of barriers of "Not knowing"

The "Process Promoter" has knowledge about the organization, for instance about the structure and processes. He/she is the connector between the "Functional Promoter", the "Power Promoter" as well as all other persons connected to the innovation process. The Process Promoter is oftentimes the project lead. His/her main tasks are to promote the information exchange between the "Functional Promoter" and "Power Promoter" and to overcome barriers of "Not permitted".

As soon as an innovation project exceeds the company's boundary a "Relationship Promoter" is required e.g. the cooperation with research laboratories or other companies. A "Relationship Promoter" possesses a good network and has good personal relationships with the most important stakeholders. His/her main tasks are to find the right innovation partners, to undertake contract negotiations and if necessary to take the role of mediator. Furthermore he/she is responsible for overcoming barriers of "Not knowing each other", "Not permitted to collaborate" and "Not willing and able to collaborate". (Fichter, 2009)

Within the innovation process of CIS technology, four promoters can be identified:

- Professor Dr. Werner H. Bloss was one of the pioneers within thin-film technology. In October 1970 he was appointed by the University of Stuttgart as director for gas discharge technology and photo electronic. After taking over this role, the institute was renamed to IPE. Furthermore, he initiated the foundation of the ZSW, in order to continue with IPE fundamental research within $\mathrm{CIS}$ technology. Professor Dr. Werner $\mathrm{H}$. Bloss died on the $6^{\text {th }}$ June 1995.

His promoter role was mainly the role as "Functional Promoter" and as "Relationship Promoter" based on his role within the foundation of the ZSW.

- Professor Dr. Hans Albrecht was research director for Daimler-Benz and switched to the ZSW, where he was mainly responsible for the commercialization and cooperation negotiations with the Würth Gruppe. Currently he is chairman of the board of trustees.

Professor Dr. Hans Albrecht took the role as "Relationship Promoter" due to his relationship network in the economy.

- Reinhold Würth was born on $20^{\text {th }}$ of April 1935 in Öhringen. At the age of 19 he took over the company from his dad and expanded the company to the market leader in connecting and assembly technology. Reinhold Würth has three children and handed over his position as CEO to his daughter Bettina. (Würth, 20I0)

As an entrepreneur, Reinhold Würth had faith in the idea and future of CIS technology, which was the reason he took the economic risk for a pilot production line in 1999. 
Due to the fact that he was able to provide the required resources with his company and thus had the authority to push the innovation process, Reinhold Würth took the role as "Power promoter".

- Bernhard Dimmler studied electro physics at the University of Stuttgart. From 1983 until 1992 he was employed as a scientific assistant for the IPE. He did fundamental research in the area of thin-film technology. From 1992 until 1998 he established the department for material research for photovoltaic with the aim of developing production technologies for CIS Solar modules. In January 1999, he joined the board of directors of Würth Solar GmbH \& Co. KG where he was responsible for technology, research and development. Since May 2007 Bernhard Dimmler is chairman of the board of directors for Würth Elektronik Research $\mathrm{GmbH}$, which is the development partner of Würth Solar GmbH Co. KG.

Bernhard Dimmler was "Power Promoter", "Functional Promotor" and "Relationship Promotor" during the innovation process. In particular his role as "Relationship Promoter" needs to be highlighted, since Mr. Dimmler switched his job as lead of the IPE department into the board of directors of Würth Solar in 1999. Consequently, he was a promoter between research institute and industrial partner.

\subsection{Lessons Learnt by Würth Solar}

According to the expert interview, Würth Solar identified three main findings in the innovation process.

- Crucial for the success of an innovation project is "Time to Market". This means that it is essential for a company to bring the product from the idea to marketability as fast as possible.

- Consequently, an effective goal-oriented innovation process is mandatory in order to reduce the time period between idea and marketability.

- Depending on the degree of maturity of the innovation project, the scientific proportion should continuously decrease. (e.g. the withdrawal of IPE at the beginning of the large-volume production)

\section{Fazit}

After a long innovation process of around 30 years, the CIS thin-film technology is a very valuable alternative to silicon technology. Consequently, CIS thin-film technology is an important innovation for the photovoltaic sector. With further development of the production technology it will be possible to generate a high cost reduction. Furthermore, there are new application areas for CIS technology e.g. integration in clothes or as roof top for houses. Currently the company is researching a colored variant of CIS technology, which does not have the same efficiency yet.

The technology was developed in different strings all around the world. Often the development work was done in cooperation with a research institute and industrial partner. In an "ex-post" consideration, this type of cooperation can be seen as the most successful within the photovoltaic sector. In case of Würth Solar, it was the cooperation between IPE as research partner, ZSW as research and application partner and Würth Group as industrial partner, which made this cooperation successful. Another success factor for the success of CIS was the strength and persistence of the promoters.

The future challenge for Würth Solar and its cooperation partner ZSW will be the steady competition around the optimization of production technology and the increase of efficiency for CIS thin-film modules, e.g. efficiency record on pilot plant scale of Avancis with 15.1\%. (Avancis, 2010)

In addition, the competition between the different solar technologies will increase and consequently the question arises which technology will be the future. A further challenge will be the reduction of public funds for the photovoltaic sector as planned by the German government. The implication will be a higher cost pressure for the producers. Since Chinese producers can offer solar modules significantly cheaper than German producers, we think that there will be a market adjustment on the German photovoltaic market within the next few years. From our point of view one strategy is to react to the Chinese challenge by investing in R\&D activities in order to stay a step ahead technologically. 


\section{References}

AVANCIS (2010). Avancis GmbH Co. KG, Unternehmen, http://www.avancis.de/presse/pressemeldungen/anzeigen/m eldung/neuer-weltrekord-avancis-erzielt-I5I-wirkungsgrad/ [Accessed 10 February 2010].

BMU (2009). German Federal Environment Ministry (BMU). Erneuerbare Energien in Zahlen, Berlin 2009.

BRAND, L., Hoffknecht, A., Krauss, O. (2009). Semiconductor technologies. In: Bullinger, H.J. (2009) Technology Guide - Principles, Applications, Trends, Berlin, Heidelberg, pp. 66-7I.

BROCKHOFF, K. (2007). Innovationswiderstände. In: Dold, E., Gentsch P. (2007) Innovation möglich machen; Düsseldorf.

DIMMLER, B. (2009). Die CIS-Technologie - vom Labor in die Serienfertigung. Galvanotechnik 12/2009, Pp. 2824 2829.

FICHTER, K. (2009). Grundlagen des Innovationsmanagements, Oldenburg 2009.

FIRST SOLAR (2009). First Solar Inc., News Release „First Solar passes \$ I per Watt Industry Milestone“. Feb. 24, 2009.

FUHS, M. (2009). Die Nachzügler kommen. Photovoltaik 02/2009, pp. 46-53.

HANNEN, P. (2009). Wertvolles Nebenprodukt. Photovoltaik 02/2009, pp. 60-2.

HAUSCHILDT, J., Salomo, S., (2007). Innovationsmanagement. München 2007

HELMHOLTZ (2009). Helmholtz-Zentrum Berlin für Materialien und Energie. http://www.helmholtzberlin.de/angebote/arbeiten-lernen/info/solar/multimedia/ photovoltaik/energierueckzahlzeit de.html [Accessed 10 February 2010].

HIRSHMAN, W., Faidas, M., Finis, A.L., Yilin Jin, Ran Li, (2009). Verhaltenes Lächeln auf langen Gesichtern. Photon April 2009, pp. 54-7I.
IPE (2010). Institute for Physical Electronics, University of Stuttgart, 02/2010, http://www.ipe.uni-stuttgart.de [Accessed I2 February 20I0].

NREL (2004). National Renewable Energy Laboratory: PV FAQs, http://www.nrel.gov/docs/fy04osti/35489.pdf. [Accessed 18 February 2010].

PAPATHANASIOU, O. (2008). Neuer Weltrekord für Dünnschichtzelle. Photon November 2008, pp. 5 I.

RENTZING, S. (2009). Dünnschicht contra kristalline PV. Energy 2.0, September 2009, pp. 8-I0.

SCHUMPETER, J. (193I). Theorie der wirtschaftlichen Entwicklung - Eine Untersuchung über Unternehmergewinn, Kapital, Kredit, Zins und den Konjunkturzyklus, 3. Edition., Leipzig 193I.

SOLARSERVER (2008). Solarserver: Solarpark der Superlative: Weltgrößte Freiflächen-Solarstromanlage mit CIS-Technologie, 23.10.2008, http://www.solarserver.de [Accessed 10 February 2010].

SULFURCELL (2009). Sulfurcell Solartechnik: Sulfurcell Solartechnik Daten und Fakten, Berlin 2009.

UNIVERSITY OF STUTTGART (2006). Press Release 46/1996, $\quad$ www.uni-stuttgart.de/aktuelles/presse/1996 146.html [Accessed 04 February 20 I0].

VAHS/BURMESTER (2002). Innovationsmanagement, Von der Produktidee zur erfolgreichen Vermarktung, 2. Edition, Stuttgart 2002.

WK GERMAN GOVERNMENT (2003). Scientific Advisory Board of the German Federal Government Global Environmental Change (Wissenschaftliche Kommission der Bundesregierung Globale Umweltveränderungen). Hauptgutachten 2003, Welt im Wandel - Energiewende zur Nachhaltigkeit, Berlin, Heidelberg 2003.

WITTWER, V. (2009). Solar energy, in: Bullinger, H.J: Technology Guide - Principles, Applications, Trends, Berlin, Heidelberg 2009, pp. 352-357.

WÜRTH (2010). Würth Group, Kennzahlen Würth Gruppe, Januar 2010, http://www.wuerth.com/web/ de/wuerthcom/unternehmen/zahlenundfakten/zahlenundfak 
ten I/zahlenundfakten I.php [Accessed II February 2010].

WÜRTH SOLAR (2010). Würth Solar: Daten und Fakten Würth Solar, Schwäbisch Hall 2009.

ZSW (2006). Center for Solar Energy and Hydrogen Research (ZSW), Dünnschicht-Photovoltaik Technologietransfer am ZSW, in: Jahresbericht 2006 ZSW.

ZSW (2009). Center for Solar Energy and Hydrogen Research (ZSW), Press release 05/2009.

ZSW (2010a). Center for Solar Energy and Hydrogen Research (ZSW), http://www.zsw-bw.de/index.php?id=33 [Accessed I4 February 20I0].

ZSW (20lOb). Center for Solar Energy and Hydrogen Research (ZSW), http://www.zsw-bw.de/index.php?id=10 [Accessed I4 February 20I0].

\section{About the Authors}

Harald Wirtz is Commercial Director of the Fraunhofer Institute for Technological Trend Analysis in Euskirchen and lecturer at the Hochschule Fresenius University of Applied Science in Cologne, Germany. He studied Business Administration and Economics and holds a Ph.D. in Business Science. His current research interests include innovation cooperation, knowledge management and organizational change processes.

Markus Janssen is consultant for the Accenture $\mathrm{GmbH}$ in Germany. He studied International Business Administration at the University of Applied Sciences in Emden, Gemany. $\mathrm{He}$ holds a degree as "Diplom-Kaufmann (FH)". His current research interests include innovation process, innovation cooperation and financing innovations. 